\title{
Could a 1755-Like Tsunami Reach the French Atlantic Coastline? Constraints from Twentieth Century Observations and Numerical Modeling
}

\author{
S. Allgeyer, ${ }^{1,3}$ C. Daubord, ${ }^{2}$ H. Hébert, ${ }^{1}$ A. Loevenbruck, ${ }^{1}$ F. Schindelé, ${ }^{1}$ and R. Madariaga ${ }^{3}$
}

\begin{abstract}
The tsunami generated by the 1 November, 1755 earthquake off the coast of Portugal affected mainly the coastlines of the Iberian Peninsula and Northwest Morocco, but was also observed in some places along the North Atlantic coasts. To determine whether the event could have effected the French coastline, we conducted a study to search for signs of the tsunami in historical records from all tide gauge stations off the French Atlantic coast during the twentieth century, specifically for the 28 February, 1969 and the 26 May, 1975 tsunamis that were recorded by the Portuguese tide gauge network. Because many recordings are available in La Rochelle (located on the southwest coast of France), we focused our study on this harbor. The analysis of the tide gauge data shows no evidence for tsunamis in La Rochelle, neither in 1969 nor in 1975 . To confirm this lack of tsunami signals, we used nonlinear, shallow water equations to compute the tsunami propagation to the French Atlantic coastline for both 1969 and 1975 events. Results obtained from these simulations confirm otherwise unnoticeable wave amplitudes at La Rochelle harbor. In a second step, tsunamis from three different scenarios for the 1755 earthquake were modeled to estimate the impact of such a tsunami on the French Atlantic coast, with a focus on La Rochelle harbor. A comparison of the functions of tide configuration was made in order to analyse the difference in impact. The results show that, while the harbor is poorly impacted, several areas (western part of the island of Ré and northern coast of the island of Oléron) may have experienced a moderate impact from 0.5 to $1 \mathrm{~m}$, especially since the tide was high at the time of arrival, possibly causing local inundations in lowland areas.
\end{abstract}

Key words: Tsunami hazard, France, Atlantic Ocean, numerical modeling, observations.

\section{Introduction}

The northeast Atlantic, compared to other ocean basins such as the Pacific Ocean, is less affected by

1 CEA-DAM-DIF, 91297 Arpajon, France. E-mail: allgeyer@geologie.ens.fr

2 Service Hydrographique et Océanographique de la Marine Nationale, Brest, France.

3 Laboratoire de Géologie, École Normale Supérieure, 24 Rue Lhomond, 75231 Paris Cedex 5, France. great tsunamis. However, historically, some large earthquakes have occurred in this region triggering massive tsunamis, among them the 1755 Lisbon earthquake and tsunami that remain the most devastating in the history of the region (BAPTISTA and MiRANDA 2009). In agreement with the large magnitude estimated for this event $\approx M_{w} 8.5$, the evaluation of the associated macroseismic intensities has shown a maximum of at least $\mathrm{X}$ in the southwest of Portugal. Various studies based on macroseismic intensity distribution have suggested that the source of the 1755 earthquake is around $200 \mathrm{~km}$ off the coast of southwest Iberia, close to the Gorringe Bank or Marques de Pombal zones (BAPTISTA et al. 2003; GRANDIN et al. 2007).

Due to the earthquake, considerable shaking was felt throughout Europe, causing water level oscillations in lakes, ponds and harbors (REID 1914). These coseismic perturbations must be distinguished from tsunami waves that reached within the first hour after the mainshock hit Portugal and Spain, and caused considerable damage (BAPTISTA and MirAnda 2009). It was reported that the tsunami effects were felt in Morocco (Blanc 2009), the West Indies (Roger et al. 2011), and also in Great Britain and Ireland (HASLETT and Bryant 2007; Horsburgh et al. 2008). Several locations of impact are reported, such as in the county of Cork (Ireland), the Bristol Channel, and the region of Penzance in Cornwall (REID 1914, 1918) (Fig. 1).

So far, we have not confirmed reported observations that the tsunami reached other distant coastlines. Moreover, recent historical reappraisals tend to lower its estimated impact in Spain or Morocco (BLANC 2008, 2009).

Regarding France, no historical observations of tsunamis exist for the Atlantic coastlines so far, and we suspect that the tsunami events triggered in the 


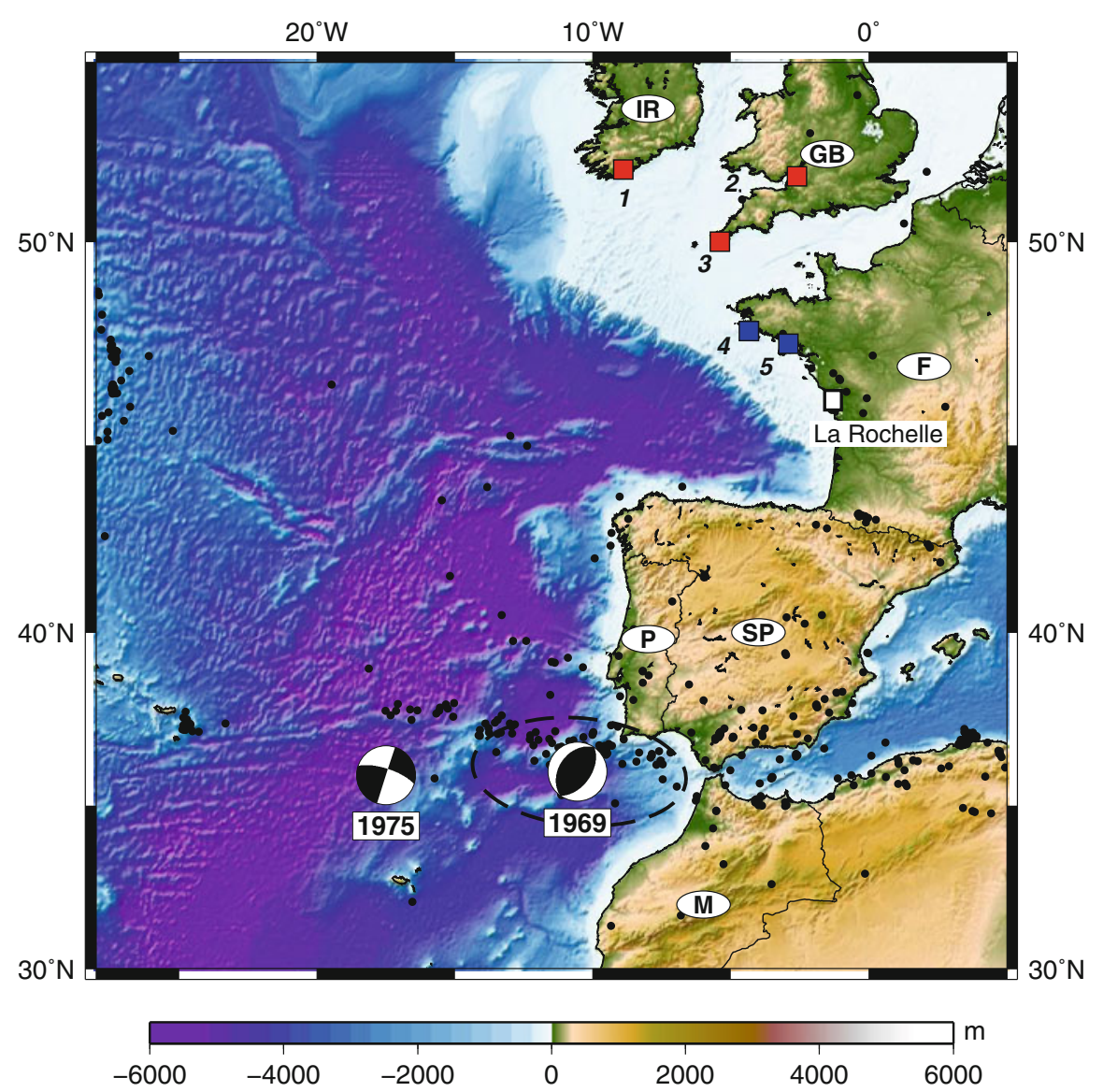

Figure 1

Context of the studied area shown with bathymetry from the General Bathymetric Chart of the Oceans (GEBCO) (IOC-BODC 2003) and focal mechanisms for the 1969 and 1975 earthquakes (see Table 4 for characteristics). The 1755 epicentral area is plotted with the dashed ellipse. Red squares indicate the probable impact of the 1755 tsunami on Ireland ( 1 county of Cork), and United Kingdom ( 2 Bristol Channel, 3 Penzance Bay). Blue squares indicate places where a relative amplification is obtained in the 1755 tsunami modeling (see text for details) ( 4 south Finistere, 5 Gulf of Morbihan). This figure also displays the La Rochelle harbor where high resolution tsunami modeling was carried out. Black dots denote the seismicity from EMSC-CSEM for the period 1998-2011 and magnitudes $M>4$ (GoDEY et al. 2006)

Gulf of Cadiz region during the twentieth century were too small to be noticed. However, in situ investigations for high-energy deposits in the region have been debated; for instance, researchers believe that high-energy incursions of water into wetlands may have occurred in the southern part of French Brittany, as evidenced by sand or gravel deposits, possibly consistent with events similar to the one in 1755. Available radiocarbon datings suggest the possibility of such an event in the eighteenth century, having affected at least Pointe de la Torche (Haslett and Bryant 2007).

In a recent attempt to investigate archived tide gauge records, Service Hydrographique et Océanographique de la Marine (SHOM), the hydrographic service of the French Navy responsible for coordinating sea level observation in France and for maintaining the national tide gauge archive, gathered and scrutinized the historical observations available. Several possible events capable of reaching the French coastlines have been identified, mainly those listed in previous works (BAPTISTA and Miranda 2009). Earthquakes such as those which occurred in 1941, 1969 and 1975 were considered, in particular, since they were responsible for tsunami waves observed in Portugal. As will be shown in this article, these investigations did not reveal any tsunami record on the French coastlines, at least for one of the harbors equipped with a tide gauge (La Rochelle), 
where records for both years 1969 and 1975 are available and do not exhibit any anomalous sea level variation.

Another objective of this study was to estimate the possible effects of the 1755 tsunami on the French coastline. Thus, our work considered the numerical modeling of the tsunami waveforms associated with the 1755 earthquake. In order to compute the full waveform propagation, we built a series of nested bathymetric grids. In the first part of this paper, we focus on the 1969 and 1975 events and their possible effects on La Rochelle harbor. Our model predicts only a few centimeters of wave amplitude, which is consistent with the lack of observations. The second part of this paper is devoted to modeling the wave propagation associated with the 1755 event. The waveforms have been deduced from the proposed source models available in international literature (BAPTista et al. 2003; Gutscher et al. 2006; JohnSTON 1996). A maximum wave amplitude of $20 \mathrm{~cm}$ is predicted on the actual tide gauge of La Rochelle; however the amplitude could have reached as much as $50-100 \mathrm{~cm}$ at other location in the vicinity of $\mathrm{La}$ Rochelle (i.e. the islands of Ré and Oléron).

\section{Observations Along the French Atlantic Coast in the Twentieth Century}

\subsection{Studied Events}

28 February 1969: off Portugal, Azore The $M_{w}$ 7.8 earthquake off the Portuguese coast was generated at 2h40 (UTC) on 28 February, 1969, located at $10.57^{\circ} \mathrm{N}, 36.01^{\circ} \mathrm{W}$ (FuKao 1973; Buforn et al. 1988). A small tsunami amplitude (less than $1 \mathrm{~m}$ ) was observed on the Portugal, Morocco and Azores tide gauges. BAPTISTA et al. (1992) and GJeviK et al. (1997) have studied these data and concluded that FuKAo's (1973) source fits well with the records from tide gauge stations.

7 September 1972: Oléron Island An earthquake of magnitude $M_{l} 5.2$ occurred at 10:26 p.m. (UTC), on 7 September, 1972, near the island of Oléron. The epicentral coordinates $\left(45.97^{\circ} \mathrm{N}-1.51^{\circ} \mathrm{E}\right)$ are located in the Atlantic Ocean between Oléron Island and the Atlantic coast (Nicolas et al. 1990; MAZABRAUd et al.
2005). Local fishermen at the harbor of Oléron island reported abnormal water waves of approximately 0.6 $\mathrm{m}$, without precision on the arrival time (BRGM 2009).

26 May 1975: Azores This earthquake of magnitude $M_{s} 7.9$ was generated at $9 \mathrm{~h} 11$ (UTC) on 26 May, 1975 , located at $17.5^{\circ} \mathrm{N}, 35.9^{\circ} \mathrm{W}$ according to the USGS. Several authors (LynNes and RufF 1985; Buforn et al. 1988) evaluated the focal mechanism as a strike-slip event with no significant dip-slip component, but it generated a small tsunami. The tsunami was recorded on tide gauges located in Portugal, Morocco, and Azores, with a maximum amplitude of $0.6 \mathrm{~m}$ at Lagos, Portugual (BAPTista et al. 2003).

\subsection{Studied Sites/Observations}

A systematic search and inventory of tide gauge records related to the tsunami events listed above was conducted at the French archive centers. Most of the maregraphic heritage is archived at SHOM. Other recordings were found in the Services Historiques de la Défense (SHD), the Institut Géographique National (IGN), harbor records, and services related to the successive civil engineering departments (TP). This investigation was facilitated by existing inventories of sea level data (Pouvreau 2008; Gouriou 2011).

Thus, data from four, two and nine tide gauge stations were examined for the events of 28 February, 1969 (Table 1), 7 September, 1972 (Table 2) and 26 May, 1975, respectively (Table 3). Most of them are records (original or copy) from float-type analog tide gauges, and are of good quality. Those from Le Havre and Dunkerque are hourly sampling data, corresponding to hourly readings from the original tide gauge records, and are unsuitable for the present study. Original records of the data from St. Nazaire and Dieppe have not been found, and the available copies are not of sufficient enough quality to be studied.

Most of the stations are located on the northern part of the French Atlantic coast (Brest, Le Conquet, Saint-Nazaire) and on the Channel coast (Dunkerque, Dieppe, Le Havre). The southernmost stations for which we have data are Bordeaux, La Rochelle and Île d'Aix (Fig. 2). 
Table 1

Inventory of existing tide gauge data related to the 28 February, 1969 event

\begin{tabular}{lllll}
\hline Harbor & Data type & Data quality & Measurement device & Source (producer) \\
\hline La Rochelle-La Pallice & A & Good & Tide gauge Saint Chamond Granat & SHOM (TP) \\
Brest & A & Good & Tide gauge OTT 3068 & SHOM (SHOM) \\
Le Havre (Sémaphore) & T (hourly data) & Not adapted & Tide gauge Saint Chamond Granat & IGN (IGN) \\
Dunkerque & T (hourly data) & Not adapted & Tide gauge Saint Chamond Granat & IGN \\
\hline
\end{tabular}

SHOM Service Hydrographique et Océanographique de la Marine, TP the French Department(s) of civil engineering, IGN Institut Géographique National, $A$ analogical tide gauge record, $T$ tabulation

Table 2

Inventory of existing tide gauge data related to the 7 September, 1972 event

\begin{tabular}{lllll}
\hline Harbor & Data type & Data quality & Measurement device & Source (producer) \\
\hline La Rochelle-La Pallice & A & Good & Tide gauge Saint Chamond Granat & SHOM (TP) \\
Le Havre (Sémaphore) & T (hourly data) & Not adapted & Tide gauge Saint Chamond Granat & IGN (IGN) \\
\hline
\end{tabular}

SHOM, TP, and IGN abbreviations are the same as Table 1

Table 3

Inventory of existing tide gauge data related to the 26 May, 1975 event

\begin{tabular}{lllll}
\hline Harbor & Data type & Data quality & Measurement device & Source (producer) \\
\hline Bordeaux & A & Good & Tide gauge OTT & SHOM \\
St. Nazaire & A (copy) & Bad & Tide gauge Brillié & IGN \\
La Rochelle_La Pallice & A & Good & Tide gauge Saint Chamond Granat & SHOM \\
Brest & A & Good & Tide gauge OTT & SHOM (SHOM) \\
Île d'Aix & A & Good & Tide gauge OTT & SPC LA (TP) \\
Le Conquet & A & Good & Tide gauge OTT R16 & SHOM (SHOM) \\
Le Havre (dredging) & T (hourly data) & Not adapted & Tide gauge Saint Chamond Granat & IGN (SD PAH) \\
Dieppe & A (copy) & Bad & Tide gauge Brillié & IGN \\
Dunkerque & T (hourly data) & Not adapted & Tide gauge Saint Chamond Granat & IGN \\
\hline
\end{tabular}

SHOM, TP, IGN abbreviations are the same as in Table 1. SPC LA flood forecasting service of the Atlantic coast, SD PAH dredging service of Le Havre harbor

For the event of 1969 and 1975, only La Rochelle harbor records show visible sea level oscillation that could contain long waves related to tsunami.

\subsection{Tidal Data Analyses}

Tide gauge records were digitized at a 1 minute sampling rate using Numerisation des Niveaux d'Eau (NUNIEAU) software developed by UlLmann et al. (2005). The methodology used to analyse signal contents is inspired from the one described by RABINOVICH et al. (2006). Digitized height series were first compared to tide prediction calculated with the MAS software
(Foreman et al. 2009; SimON 1991, 2007). Comparison with theoretical tides enabled us to check the time system, time and height scales and to detect possible time shifts in the records. Residual height series (surges) were then filtered through a high-pass Butterworth filter with a $2.8 \times 10^{-4} \mathrm{~Hz}$ cutoff frequency (period of $1 \mathrm{~h}$ ). This enabled us to remove barometric effects and residual tide components due to possible time shifts between predictions and observations. Wavelet transform technique was used for the time-frequency analysis of the filtered signal, because a simple spectral analysis (Fourier transform) does not provide time information on the arrival of these frequency. 


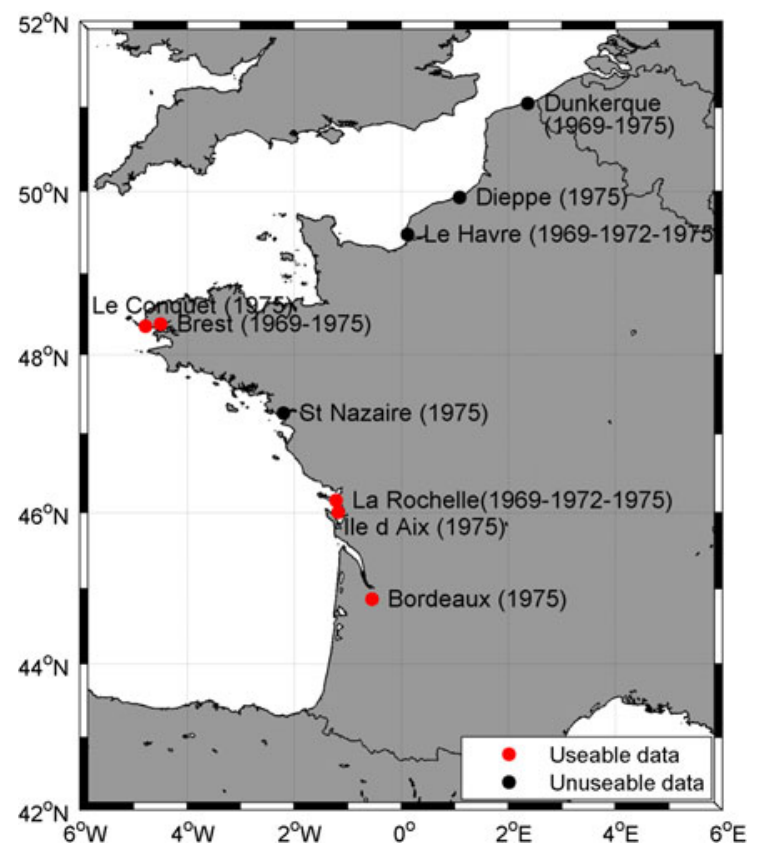

Figure 2

Location of tide observatories where data were found for the 1969 , 1972 and 1975 event

When applied to La Rochelle data of the 28 February, 1969 event, this methodology shows that an important energetic oscillation (4 cm high zero-crest) was observed at $0 \mathrm{~h} 30 \mathrm{UT}$, thus about $2 \mathrm{~h}$ before the earthquake origin time (2h40) (Fig. 3). This may correspond to a seiche of unknown origin. However, no significant oscillations were present $3.5 \mathrm{~h}$ after the seismic event (estimated Tsunami Travel Time, labeled "T" on Fig. 3). Smaller disturbances are pointed out on the time scale representation at $10 \mathrm{~h}$ UT and $12 \mathrm{~h} 10 \mathrm{UT}$ with frequencies of 2 and $2.7 \mathrm{mHz}$, respectively. It is important to highlight that no time shift was observed between tide predictions and observations. This is in agreement with meta data that attest to a good clock operating of the tide gauge, and it allows us to be rather confident in our temporal observations.

Concerning the 26 May, 1975 event, the La Rochelle record (Fig. 4) shows a slight time shift between observations and predictions, more likely due to a physical effect (meteorological effect or displacement at the reference site between observed time and time measurement used for prediction) than to a disturbance of the tide gauge clock. Some small oscillations are present $4 \mathrm{~h}$ after the mainshock (estimated Tsunami Travel Time, labeled "T"), but without relevant amplitudes. The most significant highfrequency oscillations were recorded on 27 February at $2 \mathrm{~h} 50 \mathrm{UT}$ (18 $\mathrm{h}$ after the mainshock), with rather small amplitudes (less than $10 \mathrm{~cm}$ crest-to-trough) that decreased rapidly below noise levels after $2 \mathrm{~h}$. This is probably a seiche oscillation quite similar to the one observed in 1969 before the earthquake.

\section{Numerical Simulation of Tsunamis Triggered by Earthquakes Offshore Portugal}

\subsection{Numerical Modeling}

The computation of the tsunami propagation is based on hydrodynamic equations, under the nonlinear shallow water approximation. In the most cases, these equations are divided into a set of two hyperbolic equations, containing an equation of motion,

$$
\frac{\partial \vec{u}}{\partial t}+(\vec{u} \cdot \vec{\nabla}) \vec{u}+\vec{f} \times \vec{u}=-\vec{g} \nabla \eta,
$$

and an equation of continuity,

$$
\frac{\partial(\eta+h)}{\partial t}+\nabla \cdot(\vec{u}(\eta+h))=0 .
$$

In these equations, $\vec{u}$ denotes the velocity field integrated over the water column, symbolized by the mean sea level height $(h)$ and the sea level disturbance $(\eta)$. The Coriolis parameter is denoted by $f$, and $g$ denotes the acceleration of gravity. For these simulations, the contribution of the Coriolis forces and the bottom friction are not solved. The open boundaries are solved using a Sommerfield radiation condition,

$$
\frac{\partial(\eta+h)}{\partial t}-c \frac{\partial(\eta+h)}{\partial x}=0
$$

where $c$ is the nondispersive wave velocity of the tsunami wave $(\sqrt{g \cdot h})$. Neumann boundary equation,

$$
\vec{u} \cdot \vec{n}=0
$$

is used for the wet-dry boundary (total reflection). So, no inundation is computed in this study.

This set of equations is solved with a finite difference numerical code using a CRANK and NICOLSON (1947) scheme on a series of nested bathymetric grids to take account of the different shoaling effects that occur 
(a) $28 / 02 \mathrm{OH}(\mathrm{UT})$

28/02 2H(UT)

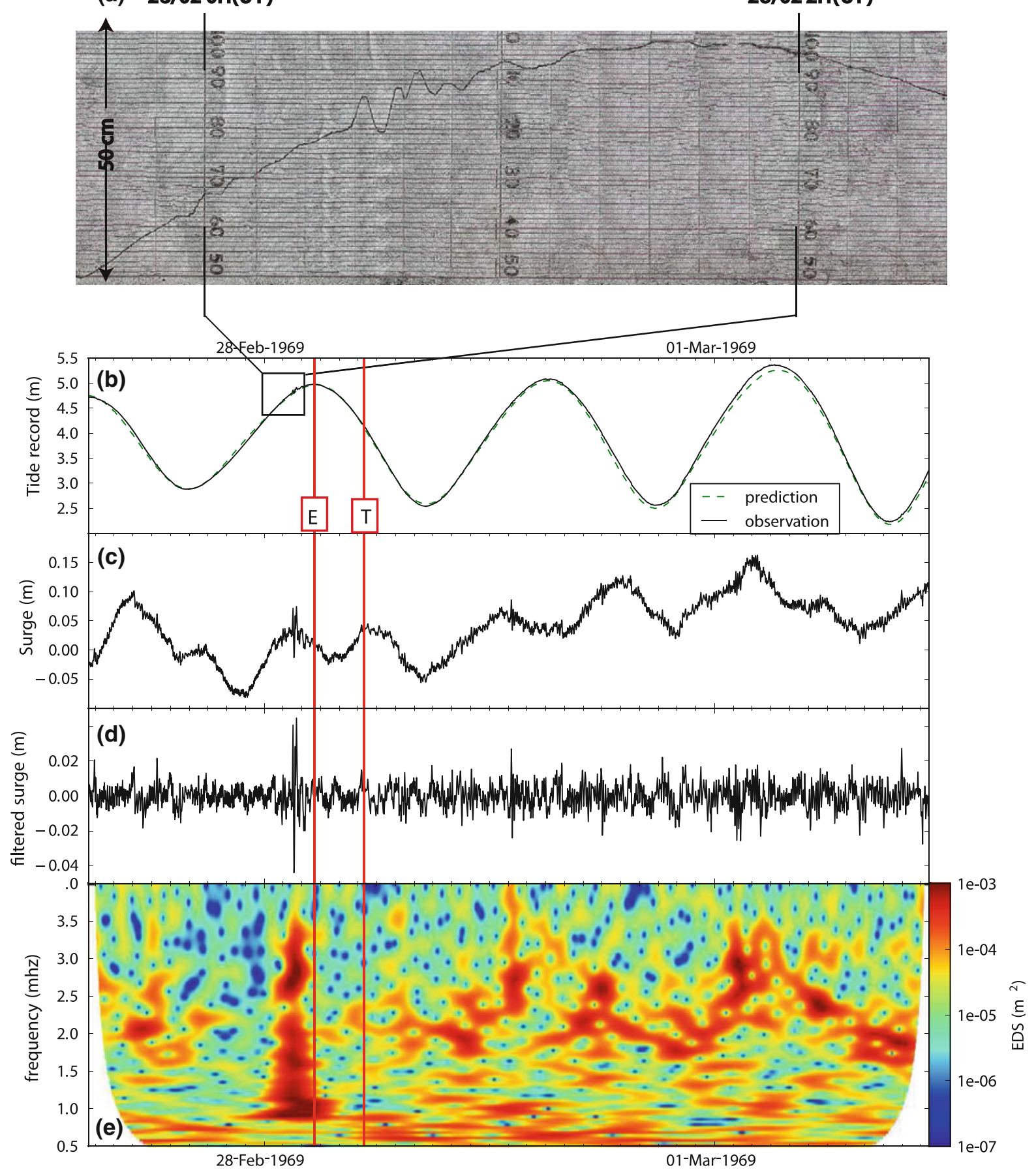

Figure 3

Analysis of the tide gauge observations in La Rochelle harbor following the Azores earthquake of February 28, 1969. a Extract of the centimeter-detailed curve of the original tide gauge record. Zoom on the major oscillations recorded but unrelated to the tsunami. $\mathbf{b}$ Plot of the 1 min digitized sea level record and comparison to tide predictions. c Calculation of the detided series (surge signal). $\mathbf{d}$ Calculation of the high pass filtered series (filtered signal). e Frequency-time plot of the high pass filtered series. The dashed vertical line labeled "E" indicates the time of the mainshock of the earthquake and the label " $\mathrm{T}$ " indicates the theoretical tsunami arrival 


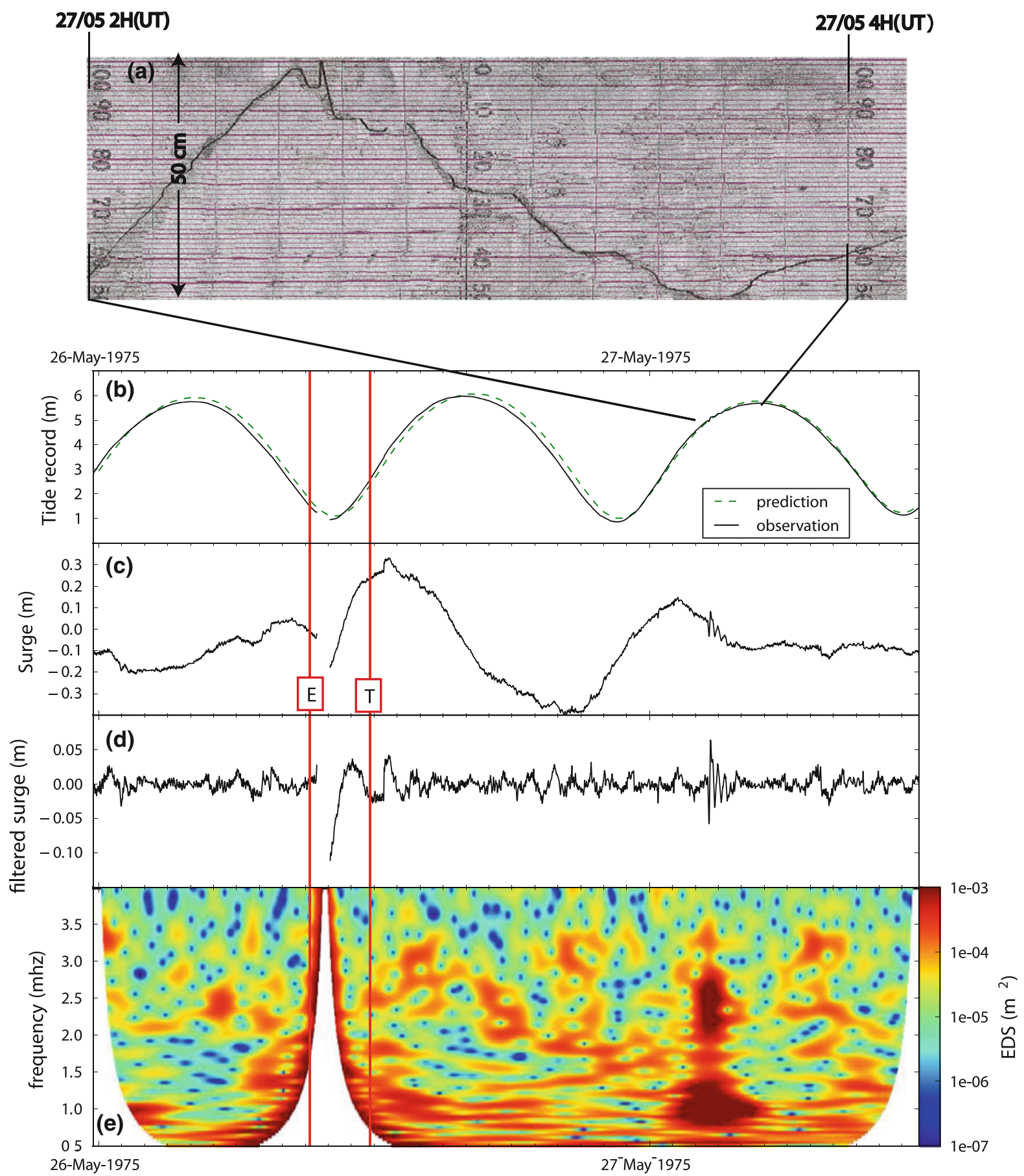

Figure 4

Analysis of the tide gauge observation in La Rochelle harbor following the Azores earthquake of May 26, 1975. a Extract of the centimeterdetailed curve of the original tide gauge record. Zoom on the major oscillations, occurring $17 \mathrm{~h}$ after the earthquake. b Plot of the $1 \mathrm{~min}$ digitized sea level record and comparison to tide predictions. $\mathbf{c}$ Calculation of the detided series (surge signal). $\mathbf{d}$ Calculation of the high pass filtered series (filtered signal). e Frequency-time plot of the high pass filtered series. The dashed vertical line labeled " $\mathrm{T}$ " indicates the time of the tsunami arrival computed by simulation 
close to the shores. This model has been tested and validated in numerous cases (see, for example, HÉBERT et al. 2007; SAHAL et al. 2009). The initial seismological deformation is based on the homogeneous elastic half-space deformation (ОкADA 1985) constrained by seismological parameters of the rupture that satisfy the expression of the moment magnitude,

$$
M=\mu U L W,
$$

where $\mu$ denotes the rigidity of the medium, $U$ the average slip along the fault of length $L$ and width $W$.

\subsection{Nested Grids}

The wave propagation was calculated from the epicentral area across the northwest Atlantic Ocean. We used a set of six nested grids with an increasing resolution to take into account a better description of shorter waves when they approached our area of interest, namely the French Atlantic coast and the La Rochelle harbors (Fig. 5).

The two coarser grids, corresponding to the northwest Atlantic Ocean and the entire western French coastline were generated using the GEBCO World Bathymetric Grid (IOC-BODC 2003) with a space increment of $1^{\prime}$ (Grid 0 ) and $30^{\prime \prime}$ (Grid 1). The intermediate grids were included for numerical stability during the nesting, so that the waveforms were evenly sampled at each grid level, with a resolution of $10^{\prime \prime}$ (Grid 2 ). The Grid 3 with a resolution of $3^{\prime \prime}$ was used to observe the maximum wave height near La Rochelle. The last two grids, used to compute the synthetic tide gauge in the La Rochelle harbor, were computed with a space resolution from 30 to $10 \mathrm{~m}$, again using GEBCO data, completed with single-beam bathymetric data from SHOM and with nautical charts. All the grids were interpolated with the inverse distance weighting method, and use the mean sea level as a constant term in the tide coefficient analysis.

\subsection{Seismic Sources Used}

Table 4 shows the different seismic parameters used to make the simulation. Three seismic events are studied. Two (the 1755 and 1969 earthquakes) are located closer to the Portuguese coasts than the third (the 1975 event), which is near the Azores.

For the 1969 event, we consider the Fukao (1973) source, validated by other study (GRANDIN et al. 2007), for which we have modified the strike angle from 55 to 73 in agreement with other tsunami analyses (GJEVIK et al. 1997) that better fit the

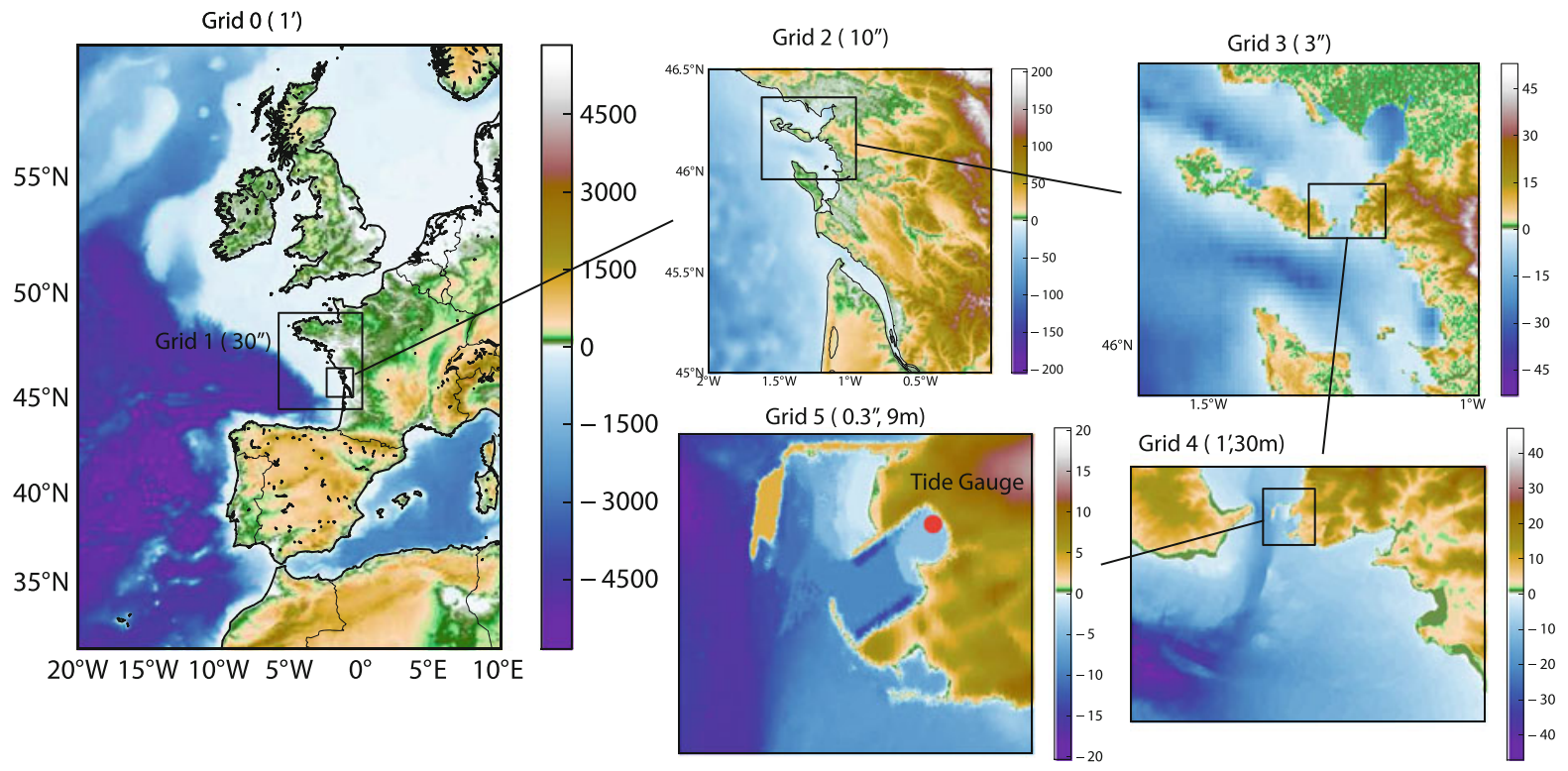

Figure 5

Set of nested grids used for the different tsunami simulations from the large scale to the La Rochelle harbor. The red circle represents the tide gauge location 
Table 4

List of the different seismic sources used for this study

\begin{tabular}{|c|c|c|c|c|c|c|c|c|c|c|c|c|}
\hline & Source & $\begin{array}{l}\text { Lat } \\
\left({ }^{\circ}\right)\end{array}$ & $\begin{array}{l}\text { Lon } \\
\left({ }^{\circ}\right)\end{array}$ & $\begin{array}{l}\text { Depth } \\
(\mathrm{km})\end{array}$ & $\begin{array}{l}\text { Slip } \\
\text { (m) }\end{array}$ & $\begin{array}{l}\text { Strike } \\
\left({ }^{\circ}\right)\end{array}$ & $\begin{array}{l}\text { Dip } \\
\left(^{\circ}\right)\end{array}$ & $\begin{array}{l}\text { Slip } \\
\left(^{\circ}\right)\end{array}$ & $\begin{array}{l}\text { Length } \\
(\mathrm{km})\end{array}$ & $\begin{array}{l}\text { Width } \\
(\mathrm{km})\end{array}$ & $\begin{array}{l}\text { Rigidity } \\
(\mathrm{GPa})\end{array}$ & $M_{w}$ \\
\hline 1969 & FUKAO (1973) & 36.01 & -10.45 & 33 & 3.85 & 235 & 52 & 55 & 80 & 50 & 65 & 7.9 \\
\hline 1975 & LYNNES and RUFF (1985) & 35.9 & -17.5 & 33 & 11 & 288 & 72 & 184 & 80 & 20 & 50 & 7.8 \\
\hline \multirow[t]{5}{*}{1755} & JOHNSTON (1996) & 36.95 & -11.45 & 27 & 13.1 & 60 & 40 & 90 & 200 & 80 & 60 & 8.7 \\
\hline & BAPTISTA et al. (2003) & 36.1 & -8.7 & 20.5 & 20 & 250 & 45 & 90 & 155 & 55 & 30 & 8.5 \\
\hline & GUTSCHER et al. (2006) & 36.8 & -10 & 20.5 & 20 & 21.7 & 24 & 90 & 96 & 55 & 65 & 8.8 \\
\hline & & 35.5 & -7.5 & 15.1 & 20 & 346 & 5 & 90 & 180 & 197 & 30 & \\
\hline & & 35.3 & -8.6 & 3.2 & 20 & 346 & 30 & 90 & 180 & 12 & 30 & \\
\hline
\end{tabular}

See also the location in the Fig. 1

observations on Portuguese tide gauges. This source corresponds to an $M_{w} 7.8$ moment magnitude. For the 1975 event, the source proposed by LyNNES and RUFF (1985) was used: a right lateral strike-slip with a small vertical component located near the Gloria transform, $200 \mathrm{~km}$ to the south, in this area of diffuse plate boundary (LYNNES and RUFF 1985). The moment magnitude is $M_{w} 7.9$.

Three different seismic sources were used for the 1755 earthquake. The first model by JoHNSTON (1996) ( $M_{w}$ 8.7) suggests that the earthquake was generated in the Gorringe Bank, a topographic feature that extends from about 10.5 to $12.5 \mathrm{~W}$ in a NE-EW direction, a location also preferred from strong motion modeling (GRANDIN et al. 2007). Based on original high-resolution offshore data and tsunami modeling, the second model of BAPTISTA et al. (2003) ( $M_{w}$ 8.5) suggests that there is a double segment source including the Marques de Pombal thrust fault (MPTF) and a thrust fault oriented along the Guadalquivir Bank (GB). The last one, Gutscher et al. (2006) $\left(M_{w} 8.8\right)$, suggests that the source fault is located in a subduction zone that presumably exists beneath Gibraltar.

\section{Results}

\subsection{The 1969 and 1975 Tsunamis}

Figure 6 shows the maximum wave height obtained for each computed source, (a) for the 1969 earthquake, (b) and the 1975 earthquake. Results on a large scale show that for both events, the coasts of northern Europe were not affected by the maximum radiated energy, which was oriented to the north (1975) or northwest (1969). Maximum amplitudes close to the source reached about $1 \mathrm{~m}$ very locally, while at distances, the maximum amplitude did not exceed a few centimeters. Maximum amplitudes of about $0.4 \mathrm{~m}$ were obtained for the 1969 tsunami, for south Portuguese coastlines and the Gulf of Cadiz in Spain. The impact of the 1975 tsunami, was distributed more evenly all along the Portuguese coastline, and less in the Gulf of Cadiz.

A striking relative amplification occurred on the continental margin off the British Isles and French Brittany, where submarine bathymetric gradients (canyons and ridges) refocused the tsunami amplitudes towards southern Ireland and Cornwall, especially, with maximum amplitudes of a few centimeters as well. To a lesser extent, a similar focusing occurred towards French Brittany, especially towards north Finistère, south Finistère and Gulf of Morbihan, placing the corresponding coastlines at a relatively higher level of exposure to this kind of tsunami arrival. These results also coincide rather well with the sites investigated by HASLETT and BRYANT (2007). Overall for the French coast, maximum wave amplitudes varied from approximately $46^{\circ} \mathrm{N}$ (French Brittany) to $48^{\circ} \mathrm{N}$ (estuary of the Gironde), while the southern coastal portion towards the Spanish border seems to have been less impacted. This is due to the protection provided by the Iberian peninsula against direct tsunami impact.

Looking closer to our site of interest in $\mathrm{La}$ Rochelle, Fig. 7 shows the maximum wave height on the grid of finer resolution; as inferred from the large 
(a)

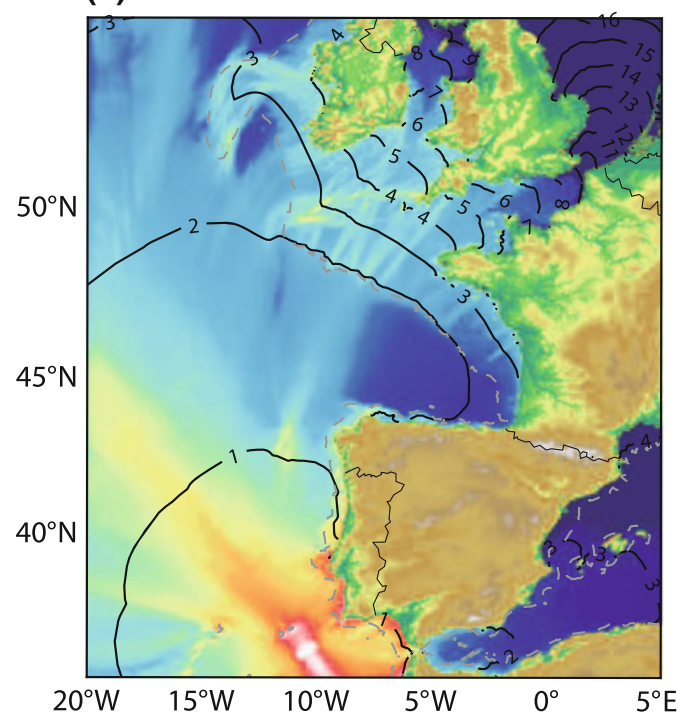

(b)

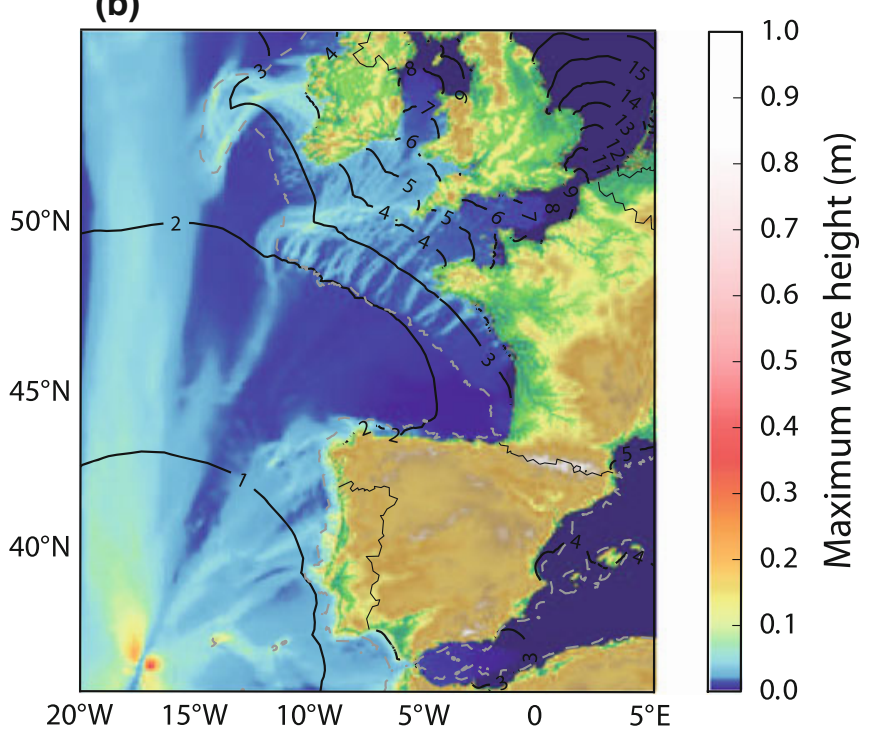

Figure 6

Maximum wave heights modeled for each events: a 1969, b 1975, black lines indicate the isochrons of the Tsunami Travel Time (plotted each hour) (a)

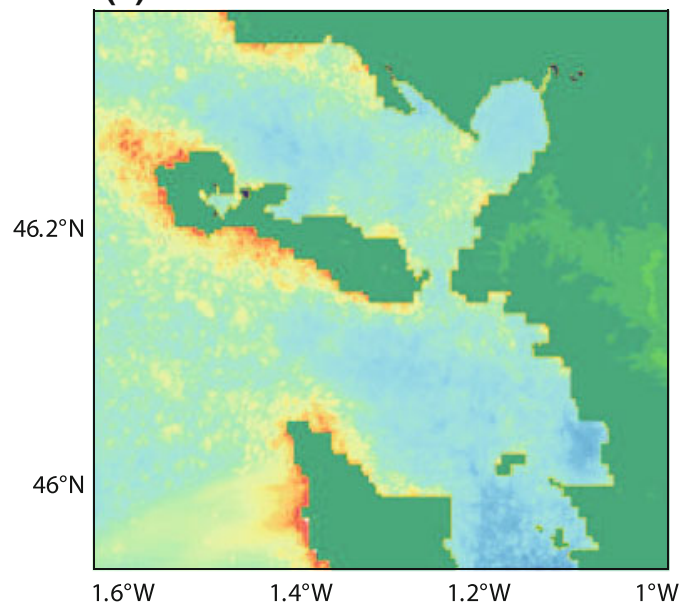

(b)

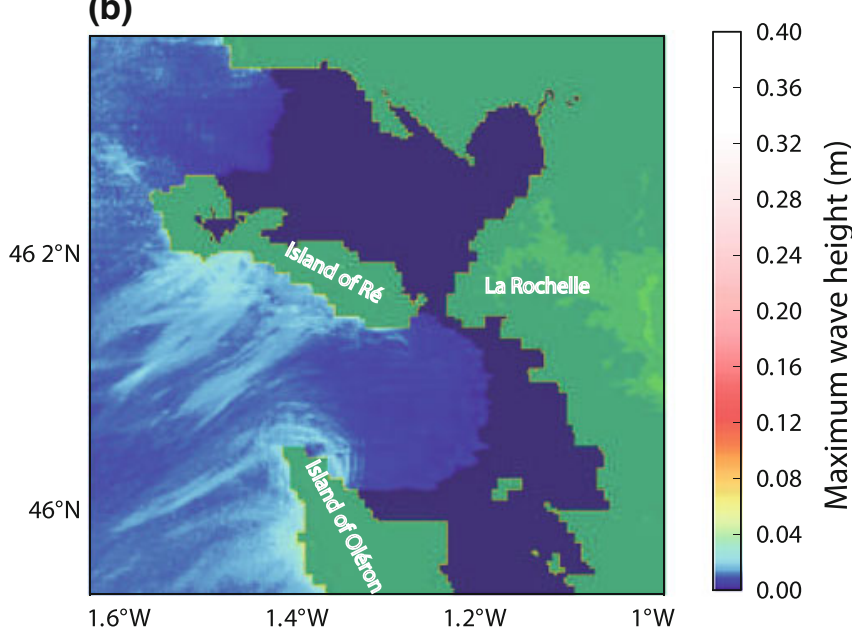

Figure 7

Maximum wave heights for each simulated event in the area of La Rochelle: a 1969, b 1975 scale view, the La Rochelle site was located in weakly affected areas for both 1969 and 1975 tsunamis (Fig. 6). The overall impact of the 1969 event does not exceed a few centimeters, especially in La Rochelle, with values of $0.2 \mathrm{~m}$ in the western and southern parts of the island of Ré. Similar values were recorded on the northern part of the island of Oléron. By contrast, the straits between the island of Ré and La Rochelle seems to have been more protected, with maximum amplitudes of a few centimeters only. For the 1975 event, the numerical simulation showed no expectation of tsunami waves in this region.

\subsection{Constraints on the 1755 Tsunami}

Considering three different sources for the 1755 event, we computed the maximum water heights 
(a)

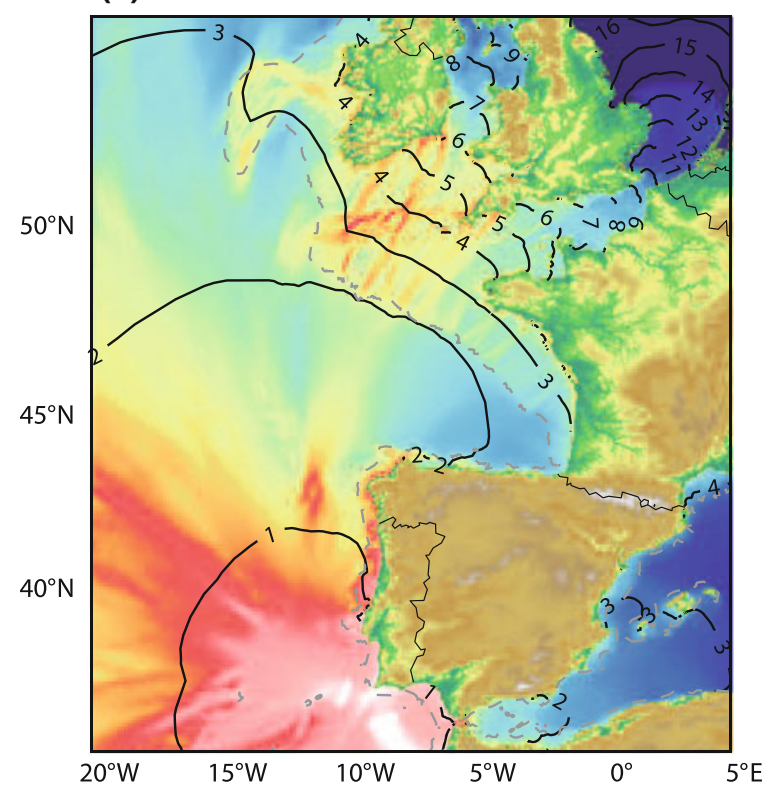

(b)

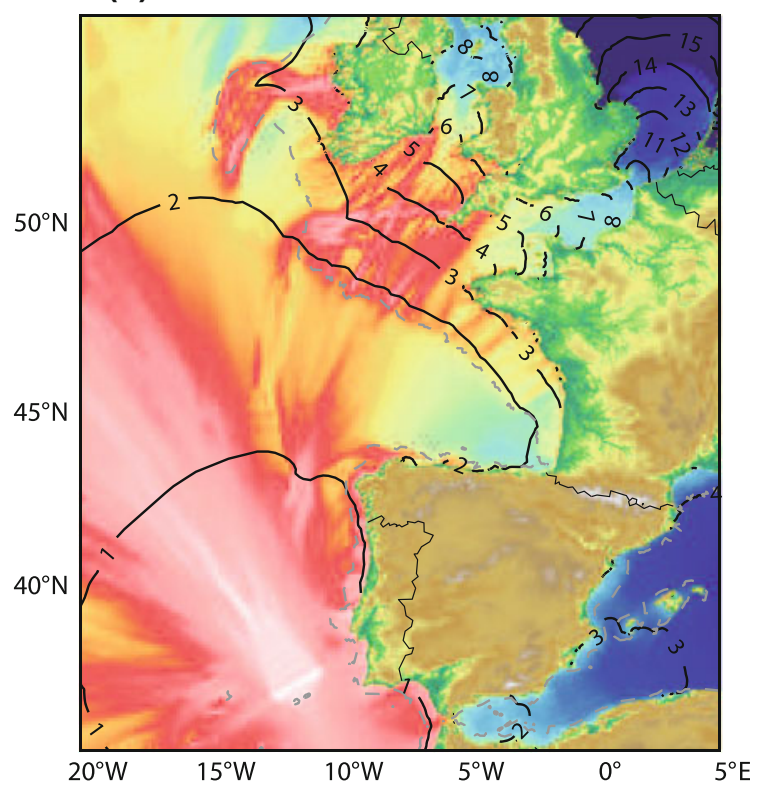

(c)

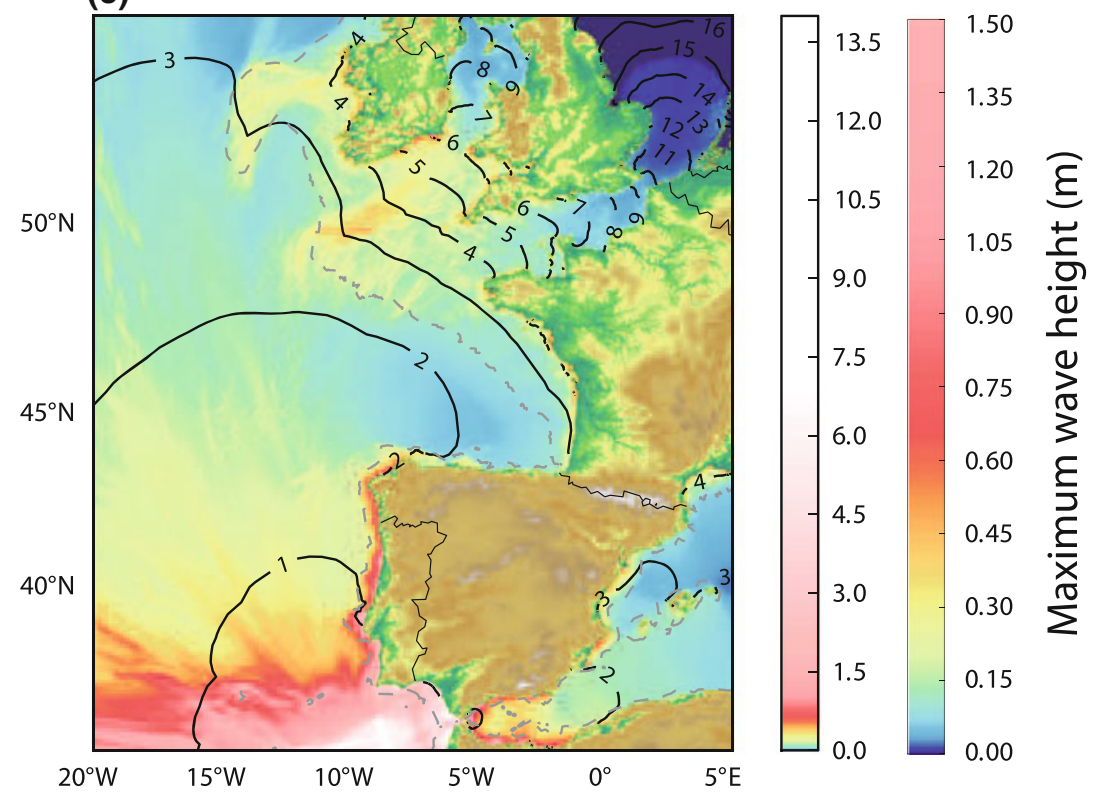

Figure 8

Maximum wave heights for each modeled events: a JoHNSTON (1996), b BAPTISTA et al. (2003), c GuTSCHER et al. (2006), black lines represent the isochrons of the Tsunami Travel Time (plotted each hour)

obtained in the northeast Atlantic (Fig. 8). For all sources, the maximum wave amplitude at the center of the source reached more than $10 \mathrm{~m}$ locally, especially the BAPTISTA et al. (2003) source.
Depending on the source azimuth, the maximum radiation patterns were oriented towards the western (source of BAPTISTA et al. 2003; source of GUTSCHER et al. 2006) or northern (source of JoHnSTON 1996) 
Atlantic Ocean, due to the theoretical radiation patterns of tsunami energy (OKAL 1988). Then, submarine features also trapped the energy (SATAKE 1988), especially off the northwest Iberian peninsula. Maximum water heights reached almost $1 \mathrm{~m}$ in many places, especially with the JoHNSTON (1996) source for the geographical frame considered in our study. These values are not surprising for such a strong magnitude event.

As for the 1969 and 1975 tsunamis, the maximum amplitudes were also recorded in southern Portugal and the Gulf of Cadiz with values exceeding $1 \mathrm{~m}$ at some coastal points; these measurements preceded the final amplification not accounted for at this level of modeling, but were consistent with destructive amplitudes of several meters frequently reported (BLANC 2008, 2009)

Figure 8 also reveals that both sources led to reamplification towards the British Isles and, less significantly, towards part of the French Atlantic coastline. For the Johnston (1996) source, amplitudes from 0.5 to $1 \mathrm{~m}$ were obtained off the western and southern coasts of Ireland, as well as offshore Cornwall. Sources from BAPTISTA et al. (2003) and GuTsChER et al. (2006) yielded lower impact for these areas. Two areas of French Brittany, already pointed out for the 1969 and 1975 tsunamis, were also impacted by amplitudes of 0.6 to $0.8 \mathrm{~m}$. For the BAPTISTA et al. (2003) and GuTSCher et al. (2006) sources, the same coastal zones were highlighted, but with amplitudes about half as big as for the Johnston source, thus not exceeding $0.5 \mathrm{~m}$.

Using a refined bathymetric grid (Fig. 9) allowed us to highlight the same geographical places as the 1969 and 1975 models. The western and southern part of the island of Ré exhibited maximum amplitudes of $0.5 \mathrm{~m}$ (sources from BAPTISTA et al. 2003; sources from GUTSCHER et al. 2006) to $1 \mathrm{~m}$, similar to the northern coast of the island of Oléron. The straits between the island of Ré and La Rochelle is impacted by maximum amplitudes of 0.3 to $0.5 \mathrm{~m}$, depending on the source.

\section{Discussion}

In this study, we tried to explore the possible impact of the 1755 tsunami on the French Atlantic coastlines, with the help of actual records of the twentieth century, for a tide gauge in the harbor of $\mathrm{La}$ Rochelle. However, the records gathered by SHOM do not display any tsunami signal, for neither the 1969 nor the 1975 tsunami. By contrast, the modeled impact of the 1755 tsunami seems to be more significant, yet moderate.

\subsection{Validity of the Tsunami Models for the Twentieth Century Events and Implications for 1755}

For La Rochelle, Fig. 10 shows the results of a synthetic gauge located in the harbor for all the simulated events. Given the small crest-to-trough amplitudes obtained for the 1969, the amplitude of high frequency numerical noise is important. Thus, the resulting computed synthetic tide gauges were filtered to keep only the periods greater than 2 minutes (Fig. 10a).

The analysis of these results shows that the models for the 1969 tsunamis did not produce any significant water heights in La Rochelle harbor (with a maximum crest-to-trough amplitude of $2 \mathrm{~cm}$ for both events), and no tsunami waves were expected for the 1975 event. This is in agreement with the lack of reliable signal that we revealed in section 2 . The 1755 synthetic result (Fig. 10b) showed a small sea perturbation in the harbor, of 0.3 to $0.6 \mathrm{~m}$ crest-totrough, depending on the source used, the largest one being associated with the source of JoHnston (1996). Depending on the source, the variability of the result was large, and the largest magnitude (source of GUTSCHER et al. 2006, $M_{w}$ 8.8) did not produce the largest amplitudes.

The 1969 model produced typical periods of about $20 \mathrm{~min}$. For the 1755 tsunami, while the sources of BAPTista et al. (2003) and of Johnston (1996) produced periods of about $30 \mathrm{~min}$, the source of GuTSCHER et al. (2006) exhibited a surprisingly long period not yet explained; however, it is certainly related to the longest dimensions of the source area and also to the small dip angle (about $5^{\circ}$ ) used in this source model. Even the $30 \mathrm{~min}$ period seems to be very large compared to the estimated eigen period of the basin, estimated to be about $16 \mathrm{~min}$. The quite constant water height in the different grid resolution near La Rochelle harbor led us to conclude that no 
(a)

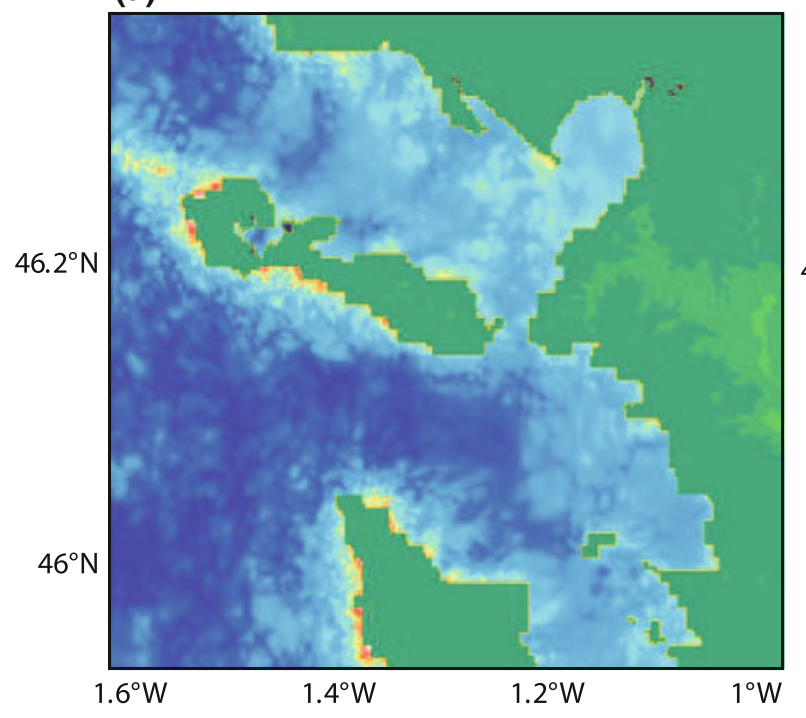

(b)

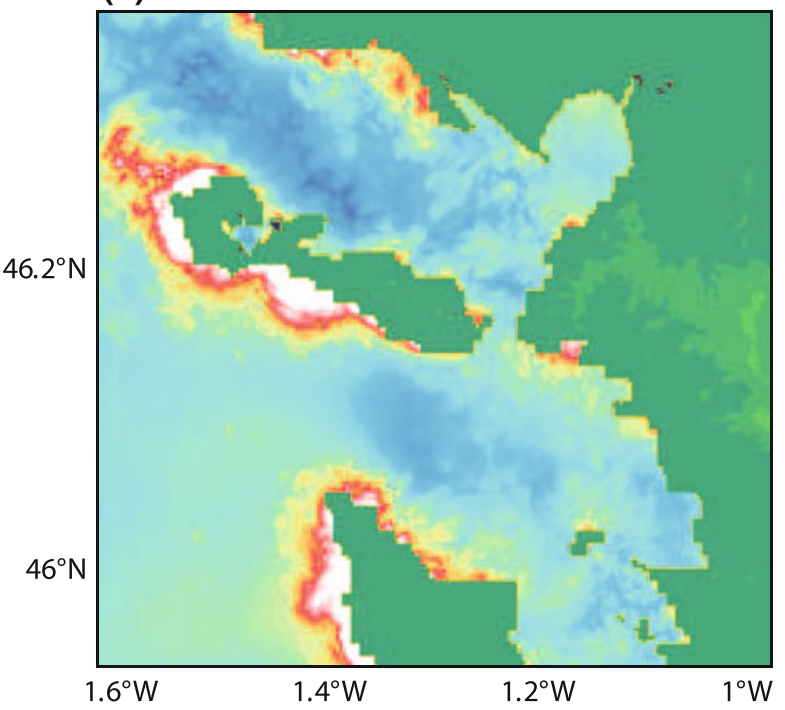

(c)

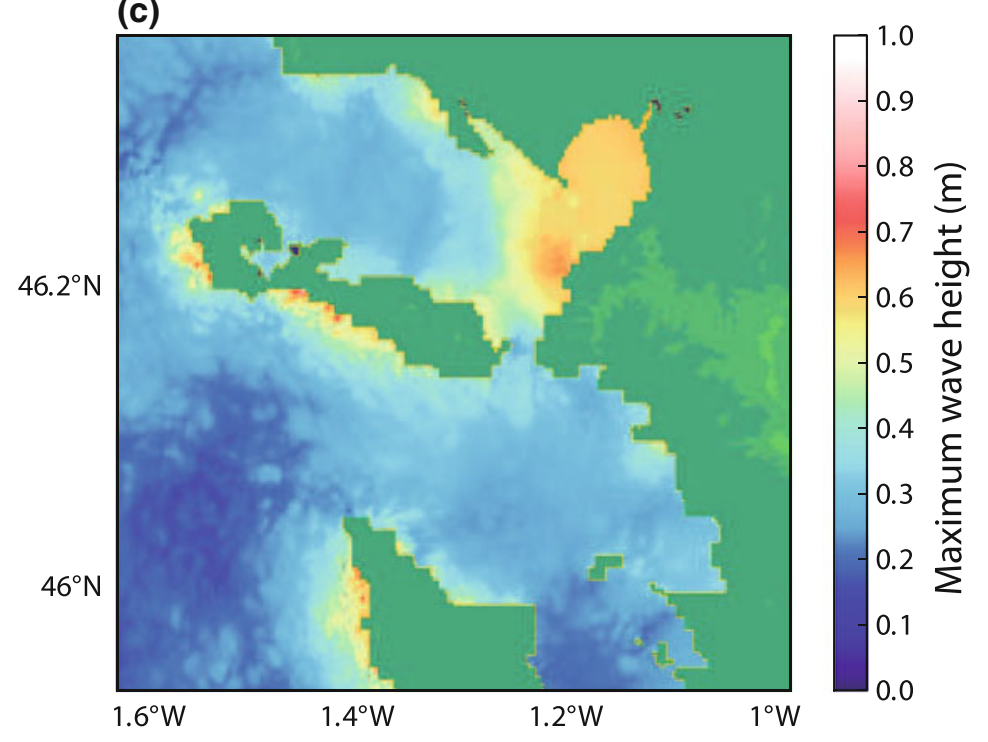

Figure 9

Maximum wave heights for each simulated events in the area of La Rochelle: a JoHNSTON (1996), b BAPTISTA et al. (2003), c GUTSCHER et al. (2006)

amplification was observed due to a resonance phenomenon.

\subsection{Effect of Tide}

It is well known that tsunami and tidal wave interaction cannot be neglected (KowALIK et al. 2006), especially in the case of small tsunami amplitudes. In this case, the combination of the tsunami wave field with high tide can make an important difference in the inundation, which we did not compute in this study. Here, we tested the effect of the tide in two cases: for high tide and low tide during strong peak-to-peak tide amplitude. We used the tide computation of the spring tide of September 2011 where the peak-to-peak amplitude reaches $5 \mathrm{~m}$ in La Rochelle harbor. Unlike other authors (BAPTISTA et al. 2011; DАо and Tкацісн 2007), who shifted the bathymetry on a constant independent of space, we used a dynamical tide model to define the tide 

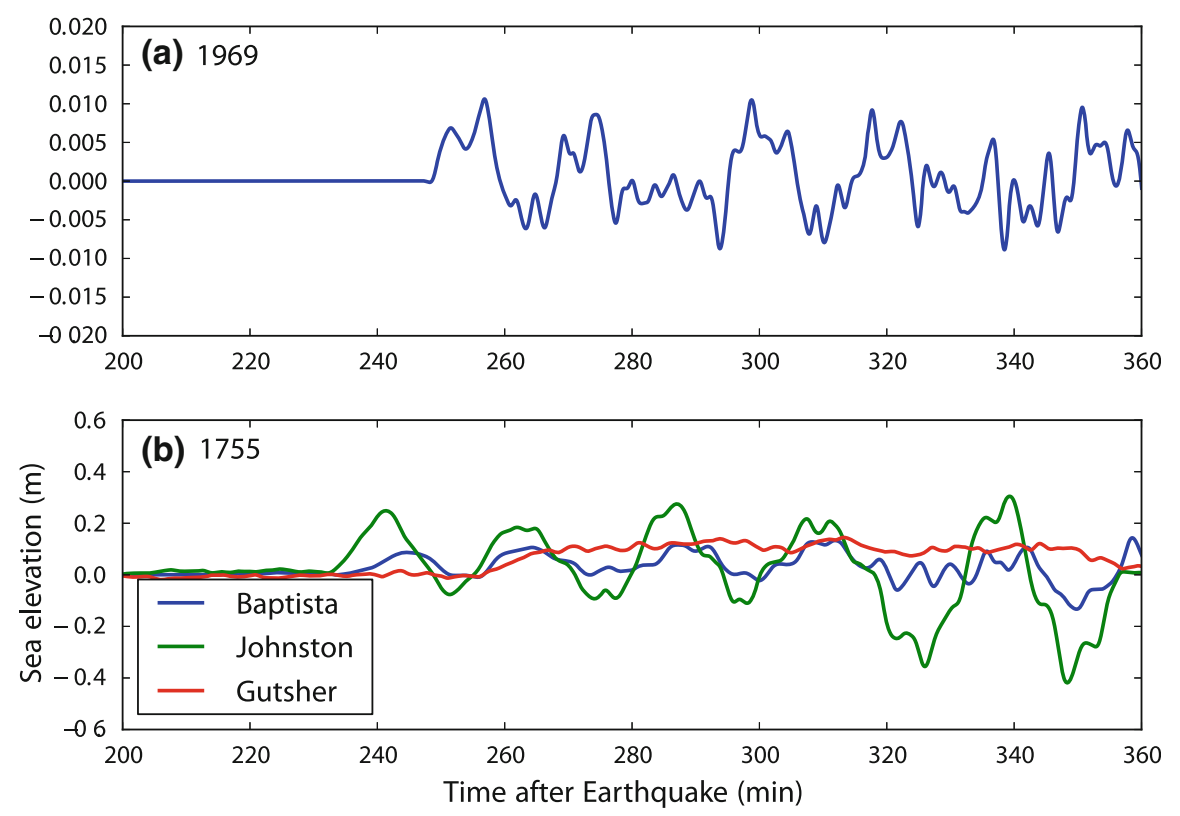

Figure 10

Synthetic tsunami signals for virtual tide gauge located in the center of the La Rochelle harbor: a 1969, b 1755 (BAPTISTA et al. (2003) in blue, JOHNSTON (1996) in green and GUTSCHER et al. (2006) in red)

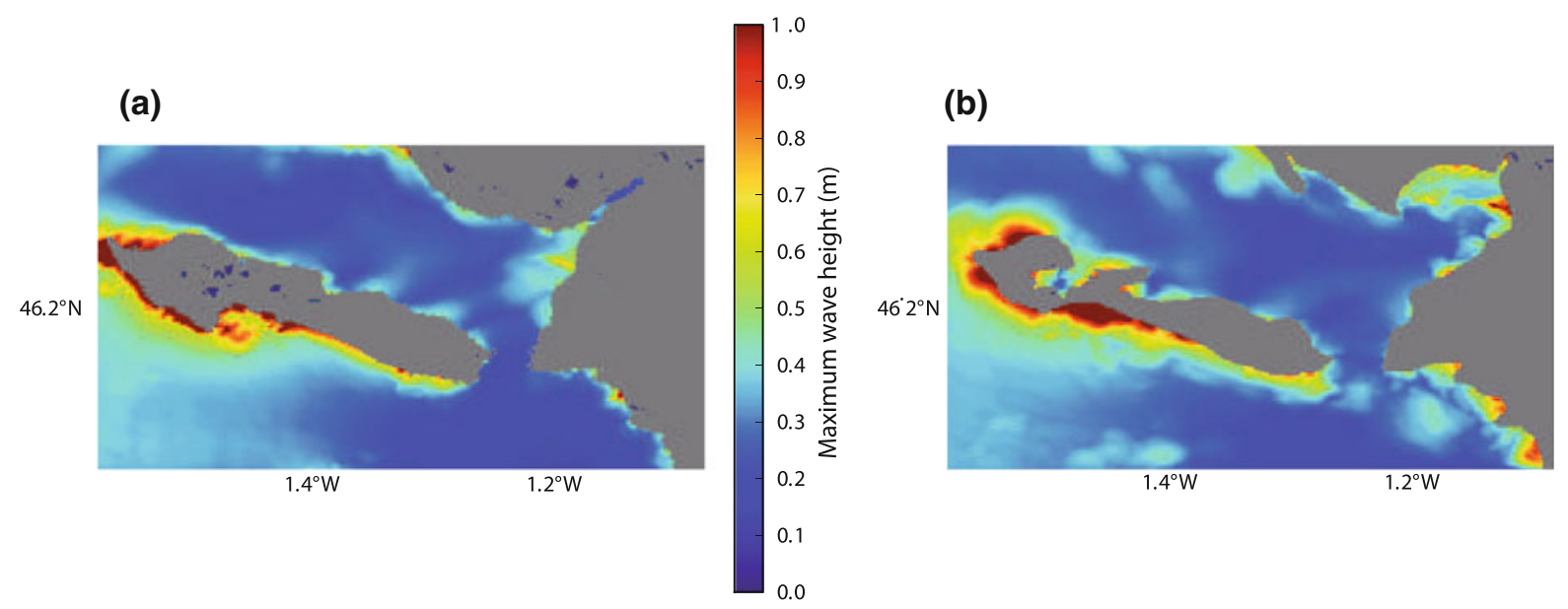

Figure 11

Maximum wave height for Gorringe source: a in low tide configuration, b in high tide for the JoHnston (1996) 1755 scenario

deviation from sea level at any point. For the tsunami simulation, we used a static bathymetry with the tide being equal to the high and low tide in La Rochelle harbors.

Figure 11 shows the maximum wave amplitudes obtained in the case of the low tide and high tide configuration. The analysis of Fig. 11 shows different impacts as a function of the tide configuration. During low tide (Fig. 11a), the maximum amplitude of the northern part of the island of Ré reached $1 \mathrm{~m}$ whereas during high tide configuration (Fig. 11b), the impact of the maximum spread over a more extended region. In any case, the impact in the area of $\mathrm{La}$ Rochelle harbor remained close to $0.2 \mathrm{~m}$.

As evidenced by theoretical tide models, the 1755 tsunami arrival in the studied area occurred close to the high tide, thus similar to the configuration shown on Fig. 11b. The most impacted areas were probably 
the western and southwestern coastlines of the island of Ré, where local inundations may have occurred on lowlands. This could be further explored through future historical or in situ investigations, as well as detailed inundation modeling, provided high resolution topographic data are available.

\subsection{Exposure to Earthquake-Related Tsunami Hazard for the Western French Coastline}

These first models also underline a relatively higher exposure of French Brittany with respect to the region of La Rochelle, whose harbor is probably well protected (no further amplification is gained from the previous grid to the harbor grid). This is the case for the 1969 and 1975 tsunamis. Looking in detail at Fig. 6 reveals that the computed amplitudes on the coarse grid may locally exceed $5 \mathrm{~cm}$ off the coast of Brittany. As the Brest tide gauge record kept in SHOM does not display any anomalous signal for either event, as in La Rochelle, we have to stress that the Brest harbor is extremely well protected at the bottom of a bay, whose entrance is very narrow, and may not record properly such small amplitudes.

Considering the results for 1755 , for which the simulations indicate Brittany was impacted by amplitudes of a few tenths of centimeters on the coarse grid, this may indicate that no further amplification is expected to occur towards places such as Brest. However, other low-lying shores that are more open to the ocean, such as the island of Ré, deserve specific investigations, either through detailed modeling or through in situ surveys in places where anthropic influence is poor. The difficulty is that these places are also among the most impacted during frequent severe storms from the Atlantic Ocean, and as such, the discrimination between such records is rather tricky.

\section{Conclusion}

We analysed the impact of tsunamis on the French Atlantic coast due to earthquakes off Portugal. After a long survey consisting of the collection of tide gauge records which could have tsunami signatures, we studied two events (1969 and 1975) in La Rochelle, where records of sea level variation are available for both years. An important step in the analysis of tide gauge data was the comparison with the theoretical tide. It allowed us to check the correct time and height information and unit system. With the help of the estimated tsunami arrival and the correct time system of our tide record, we conclude that the long period oscillations that are observed are seiche oscillations not related to tsunamis triggered by these earthquakes.

A more precise and systematic study of the entire French coast was conducted using numerical simulation of events located off the coast of Portugal. Results confirmed that the 1969 and 1975 events could not have been observed in La Rochelle harbor, but that a 1755-like tsunami could be recorded on the modern tide gauge presently operated in the harbor, with crest-to-trough amplitudes of about 20 to $40 \mathrm{~cm}$, thus possibly creating very limited disturbances in the harbor. By contrast, the western and southwestern coasts of the nearby island of Ré may have experienced greater impact from the 1755 tsunami, with maximum amplitudes of about $1 \mathrm{~m}$.

This study also led us to identify some areas on the northern part of the Atlantic (French Brittany) which seem to systematically amplify tsunami waves, probably due to canyons located on the margin of the Bay of Biscay. Considered together with places such as the island of Ré, historical and in situ investigations of these areas could help to provide a more accurate account of this event. Even though the impact is expected to be smaller than for severe storms, this may also contribute to studies on the discrimination between storm and tsunami deposits, provided poorly anthropized places can be investigated. In addition, the possibility that landsliderelated tsunamis occurred due to destabilizations on the margin of the Bay of Biscay should not be discarded, for very long times. Deposits related to such very rare events could also be discovered through such investigations.

Finally, we also observed a large variability of the results depending on the source mechanisms for the 1755-like tsunami. The early determination of focal mechanism should be stressed in the design of future warning systems under construction in the region, as a key issue to be addressed in the minutes following 
an earthquake. The plate boundary is still under discussion for several aspects; it is difficult to foresee the appropriate azimuth of the faults involved in large earthquakes. Further geophysical investigations for an improved tectonic knowledge about the area should be encouraged. Even though the impact of a 1755-like tsunami is not expected to be extreme for French coastlines, it may however be catastrophic for Portugal and Spain, and to a less extent for the Irish and British coastlines which were severely impacted in 1755 .

\section{Acknowledgments}

This work was supported by the French ANR program MAREMOTI under contract ANR-08RISKNAT-005-01. Computations were performed using HPC resources from GENCI-CCRT (Grant 2011-6702 and 2012-6702). Our study benefited from discussion and tide modeling with M. Karpytchev. We thank two anonymous reviewers for their constructive comments.

\section{REFERENCES}

Baptista M, Miranda J (2009) Revision of the portuguese catalog of tsunamis. Natural Hazards and Earth System Sciences 9:25-42

Baptista M, Miranda P, Victor L (1992) Maximum entropy analysis of portuguese tsunami data: The tsunamis of 28.02.1969 and 26.05.1975. Sci Tsunami Hazards 10(1):9-20

Baptista M, Miranda J, Chierici F, Zitellini N (2003) New study of the 1755 earthquake source based on multi-channel seismic survey data and tsunami modeling. Natural Hazards and Earth System Sciences 3:333-340

Baptista M, Miranda J, Omira R, Antunes C (2011) Potential inundation of lisbon downtown by a 1755-like tsunami. Nat Hazards Earth Syst Sci 11:3319-3326

Blanc P (2008) The tsunami in cadiz on 1 november 1755: A critical analysis of reports by Antonio de Ulloa and by Louis Godin. Comptes Rendus Geosciences 340(4):251-261. doi: 10.1016/j.crte.2007.12.001

BLANC P (2009) Earthquakes and tsunami in november 1755 in morocco: a different reading of contemporaneous documentary sources. Nat Hazards Earth Syst Sci 9(3):725-738. doi: 10.5194/nhess-9-725-2009

BRGM (2009) Tsunami database. http://www.tsunamis.fr. Accessed Nov 2011

Buforn E, Udas A, Mezcua J (1988) Seismicity and focal mechanisms in South Spain. Bulletin of the Seismological Society of America 78(6):2008-2024

Crank J, Nicolson P (1947) A practical method for numerical evaluation of solutions of partial differential equations of the heat-conduction type. In: Mathematical Proceedings of the Cambridge Philosophical Society, Cambridge Univ Press, vol 43, pp 50-67

Dao MH, Tкацich P (2007) Tsunami propagation modelling-a sensitivity study. Natural Hazards and Earth System Science 7(6):741-754. doi:10.5194/nhess-7-741-2007

Foreman MGG, Cherniawsky JY, Ballantyne VA (2009) Versatile Harmonic Tidal Analysis: Improvements and Applications. Journal of Atmospheric and Oceanic Techonology 26(4):806-817. doi:10.1175/2008JTECHO615.1

FUKAO Y (1973) Thrust faulting at a lithospheric plate boundary the Portugal earthquake of 1969. Earth and Planetary Science Letters 18(2):205-216, doi:10.1016/0012-821X(73)90058-7

Gjevik B, Pedersen G, Dybesland E, Harbitz C, Miranda P, Baptista M, Mendes-Victor L, Heinrich P, Roche R, Guesmia M (1997) Modeling tsunamis from earthquake sources near Gorringe Bank southwest of Portugal. Journal of geophysical research 102(C13):27,931-27

Godey S, Bossu R, Guilbert J, Mazet-Roux G (2006) The euromediterranean bulletin: A comprehensive seismological bulletin at regional scale. Seismological Research Letters 77(4):460-474

Gouriou T (2011) évolution des composantes du niveau marin àà partir d'observations de marégraphie effectues depuis la fin du $18 \mathrm{e}$ siècle en charente-maritime. PhD thesis, Thèse de doctorat, Université de La Rochelle

Grandin R, Borges JF, Bezzeghoud M, Caldeira B, Carrilho F (2007) Simulations of strong ground motion in SW Iberia for the 1969 February $28(M s=8.0)$ and the 1755 November $1(M \approx$ 8.5) earthquakes II. strong ground motion simulations. Geophysical Journal International 171(2):807-822, doi:10.1111/j. 1365-246X.2007.03571.X

Gutscher M, Baptista M, Miranda J (2006) The Gibraltar Arc seismogenic zone (part 2): Constraints on a shallow east dipping fault plane source for the 1755 Lisbon earthquake provided by tsunami modeling and seismic intensity. Tectonophysics 426(1-2):153-166

HASLETT S, BRyAnt E (2007) Reconnaissance of historic (post-ad 1000) high-energy deposits along the Atlantic coasts of southwest Britain, Ireland and Brittany, France. Marine geology 242(1-3):207-220

Hébert H, Sladen A, Schindele F (2007) Numerical Modeling of the Great 2004 Indian Ocean Tsunami: Focus on the Mascarene Islands. Bulletin of the Seismological Society of America 97(1A):S208-S222

Horsburgh KJ, Wilson C, Baptie BJ, Cooper A, Cresswell D, Musson RMW, Ottemller L, Richardson S, SARgeant SL (2008) Impact of a Lisbon-type tsunami on the U.K. coastline and the implications for tsunami propagation over broad continental shelves. Journal of Geophysical Research 113:C04,007. doi: 200810.1029/2007JC004425

IOC-BODC (2003) The centenary edition of the gebco digital atlas JoHnston AC (1996) Seismic moment assessment of earthquakes in stable continental regionsIII. New Madrid 18111812, Charleston 1886 and Lisbon 1755. Geophysical Journal International 126(2):314-344, doi:10.1111/j.1365-246X.1996.tb05294.x

Kowalik Z, Proshutinsky T, Proshutinsky A (2006) Tide-tsunami interactions. Science of Tsunami Hazards 24(4):242-256

LynNes CS, RufF LJ (1985) Source process and tectonic implications of the great 1975 North Atlantic earthquake. Geophysical Journal of the Royal Astronomical Society 82(3):497-510. doi: 10.1111/j.1365-246X.1985.tb05148.x 
Mazabraud Y, Bthoux N, Deroussi S (2005) Characterisation of the seismological pattern in a slowly deforming intraplate region: Central and western France. Tectonophysics 409(1-4):175-192. doi:10.1016/j.tecto.2005.08.021

Nicolas M, Santoire J, Delpech P (1990) Intraplate seismicity: new seismotectonic data in Western Europe. Tectonophysics 179(1-2):27-53

ОкаDA Y (1985) Surface deformation due to shear and tensile faults in a half-space. Bulletin of the Seismological Society of America 75(4): 1135

Окац Е (1988) Seismic parameters controlling far-field tsunami amplitudes: a review. Natural Hazards 1(1):67-96

Pouvreau N (2008) Trois cents ans de mesures marégraphiques en france: outils, méthodes et tendances des composantes du niveau de la mer. PhD thesis, Thèse de doctorat, Université de La Rochelle

Rabinovich AB, Thomson RE, Stephenson FE (2006) The Sumatra tsunami of 26 December 2004 as observed in the North Pacific and North Atlantic oceans. Surveys in Geophysics 27:647-677. doi:10.1007/s10712-006-9000-9

REID HF (1914) The Lisbon earthquake of November 1, 1755. Bulletin of the Seismological Society of America 4(2):53-80
REID HF (1918) Note on the velocity of long waves and the average depth of the ocean. Bulletin of the Seismological Society of America 8(1):34-37

Roger J, Baptista M, Sahal A, Accary F, Allgeyer S, Hébert H (2011) The transoceanic 1755 Lisbon tsunami in Martinique. Pure and Applied Geophysics 168(8):1-17

Sahal A, Roger J, Allgeyer S, Lemaire B, Hébert H, Schindelé F, LAVIGNE F (2009) The tsunami triggered by the 21 May 2003 Boumerdès-Zemmouri (algeria) earthquake: field investigations on the French Mediterranean coast and tsunami modelling. Natural Hazards and Earth System Sciences 9:1823-1834

SATAKE K (1988) Effects of bathymetry on tsunami propagation: Application of ray tracing to tsunamis. Pure and Applied Geophysics 126(1):27-36

Simon B (1991) The species concordance method of tide prediction. Progress in tidal hydrodynamics pp 725-735

Simon B (2007) La marée océanique côtière. Institut Océanographique, France

Ullmann A, Ponsm F, Moron V (2005) Tool kit helps digitize tide gauge records. Eos Trans AGU 86:38

(Received January 16, 2012, revised May 22, 2012, accepted May 29, 2012) 